\title{
Nitrogen fertilizer leaching in an Oxisol cultivated with sugarcane
}

\author{
Pablo Javier Ghiberto ${ }^{1,3}$; Paulo Leonel Libardi ${ }^{2,3 *}$; Alexsandro dos Santos Brito ${ }^{3}$; Paulo \\ Cezar Ocheuze Trivelin ${ }^{3,4}$ \\ ${ }^{1}$ UNL/FCA - Depto. de Ciencias del Ambiente, Kreder 2805, PO Box S3080HOF - Esperanza, SF - Argentina. \\ ${ }^{2}$ USP/ESALQ - Depto. de Engenharia de Biossistemas, C.P. 09 - 13418-900 - Piracicaba, SP - Brasil. \\ ${ }^{3}$ USP/ESALQ - Programa de Pós-Graduação em Solos e Nutrição de Plantas. \\ ${ }^{4}$ USP/CENA - Laboratório de Isótopos Estáveis, C.P. 96 - 13416-000 - Piracicaba, SP - Brasil. \\ *Corresponding author <pllibard@esalq.usp.br>
}

\begin{abstract}
Nitrogen $(\mathrm{N})$ leaching below the crop-rooting zone represents not only a valuable loss of nutrients for the plant, but also a potential pollution source of groundwater. The objective of this work was to quantify leaching losses of native $\mathrm{N}$ and that derived from fertilizer in an Oxisol that was cultivated with sugarcane (Saccharum officinarum) during the crop plant cycle. The sugarcane was planted and fertilized with urea in the planting furrow, with $120 \mathrm{~kg} \mathrm{ha}^{-1}$ of $\mathrm{N}$. In order to determine the fate of the fertilizer - N, four microplots with ${ }^{15} \mathrm{~N}$ enriched fertilizer were installed. Input and output of $\mathrm{N}$ at the depth of $0.9 \mathrm{~m}$ were quantified from the flux density of water and the $\mathrm{N}$ concentration in soil solution. During the evaluation period the rainfall was $141 \mathrm{~mm}$ less than the historical average $(1,315 \mathrm{~mm})$, and the climate was drier than normal in January. The average concentration of mineral $\mathrm{N}$ in soil solution was $1.8 \mathrm{mg} \mathrm{L}^{-1}$. The abundance of ${ }^{15} \mathrm{~N}$ was very high at the beginning (first week) of the assessment period and remained approximately constant $\left(0.453\right.$ atom\% of $\left.{ }^{15} \mathrm{~N}\right)$ until the end of the period. The internal drainage was $91 \mathrm{~mm}$ of water and the $\mathrm{N}$ leaching loss was $1.1 \mathrm{~kg} \mathrm{ha}^{-1}$ of $\mathrm{N}$, with only $54 \mathrm{~g} \mathrm{ha}^{-1}$ derived from fertilizer. Therefore, under high demand of $\mathrm{N}$ by the crop in a system without burning before planting, the leaching of $\mathrm{N}$ was not considerable, mainly because the surplus of water between the months of December and March was lower than expected and also because the extraction of nitrogen by the crop was high.

Key words: Saccharum spp., sustainability, solute transport, environmental quality, pollution
\end{abstract}

\section{Nitrogênio lixiviado num Latossolo cultivado com cana-de-açúcar}

\begin{abstract}
RESUMO: A lixiviação de nitrogênio (N) abaixo da zona radicular representa uma valiosa perda do nutriente para as plantas e uma fonte potencial de poluição do lençol freático. Quantificaram-se as perdas de N por lixiviação num Latossolo Vermelho Amarelo cultivado com cana-de-açúcar (Saccharum officinarum) durante o ciclo agrícola de cana-planta. A cultura foi implantada e fertilizada no sulco com $120 \mathrm{~kg} \mathrm{ha}^{-1}$ de N-uréia. Para conhecer o destino do fertilizante, foram instaladas quatro microparcelas onde o fertilizante era marcado com o isótopo ${ }^{15} \mathrm{~N}$. As entradas e saídas de $\mathrm{Na}$ a $0,9 \mathrm{~m}$ de profundidade foram quantificadas diariamente pela densidade de fluxo de água e a concentração de $\mathrm{N}$ da solução no solo. No período de avaliação, a precipitação pluvial foi 141 $\mathrm{mm}$ menor que a média histórica $(1.315 \mathrm{~mm})$ sendo janeiro mais seco que o normal. A concentração de $\mathrm{N}$ mineral média foi $1,8 \mathrm{mg} \mathrm{L}^{-1}$. A abundância de ${ }^{15} \mathrm{~N}$ foi superior à abundância natural do isótopo, especialmente no início do período de avaliação, permanecendo logo constante $\left(0,453 \%\right.$ de $\left.{ }^{15} \mathrm{~N}\right)$. A drenagem interna foi de $91 \mathrm{~mm}$ de água e a perda por lixiviação foi $1,1 \mathrm{~kg} \mathrm{ha}^{-1}$ de $\mathrm{N}$ com apenas $54 \mathrm{~g} \mathrm{ha}^{-1}$ derivados do fertilizante. Portanto, com elevada demanda de nutrientes e elevada incorporação de restos culturais, não foram registradas perdas apreciáveis de $\mathrm{N}$ por lixiviação devido ao fato de o excedente de água entre os meses de dezembro e março ter sido menor que o esperado e pela elevada extração de $\mathrm{N}$ pela cana-de-açúcar.

Palavras-chave: Saccharum spp., sustentabilidade, transporte de solutos, qualidade ambiental, poluição
\end{abstract}

\section{Introduction}

Since the initiation of the Proalcohol program in Brazil in 1975, sugarcane (Saccharum officinarum) for producing ethanol for fuel has increased in cultivated area and productivity, mainly in the São Paulo State. The expansion of ethanol production from sugarcane generates discussions about social and environmental issues (Goldemberg et al., 2008; Hartemink, 2008; Uriarte et al., 2009), with emphasis in the agricultural sector on the use of management systems that avoid negative impacts on soil, water and biodiversity (Goldemberg et al., 2008; Hartemink, 2008; Martinelli and Filoso, 2008).

Under this context, fertilization with nitrogen $(\mathrm{N})$ should be carefully assessed for sustainability because high $\mathrm{N}$ use efficiency is directly related to lower risk of groundwater and air pollution, smaller losses of nutrients by leaching and lower risk of soil acidification, besides the direct benefits of increased sugarcane productivity and decreased production costs. One of the main 
problems with nitrogen fertilization in sugarcane is the low $\mathrm{N}$ recovery by the crop (Hartemink, 2008), between 10 to $40 \%$ as measured in the field using ${ }^{15} \mathrm{~N}$ tracer isotope (Chapman et al., 1994; Trivelin et al., 1995; Vallis et al., 1996). Thus, the portion of $\mathrm{N}$ not used by the crop may remain in the soil, be incorporated as organic matter, be lost to the atmosphere or leach below the root zone where crops effectively extract water and nutrients.

In São Paulo State, there are few studies on $\mathrm{N}$ leaching by means of direct monitoring in the field, especially with doses higher than normally used during the sugarcane crop plant cycle $\left(30\right.$ to $90 \mathrm{~kg} \mathrm{ha}^{-1}$ of $\mathrm{N}$, Cantarella et al., 2007). We hypothesize that doses of $\mathrm{N}$ higher than those normally used will originate leaching of $\mathrm{N}$. Considering that this is important to find explanatory variables for predicting or explaining $\mathrm{N}$ leaching, and to generate information that allows the planning of sustainable crop management practices, the objective of this study was to quantify the leaching loss of native nitrogen and that derived from fertilizer in an Oxisol of the State of São Paulo (Brazil) cultivated with sugarcane during the agricultural cycle of the crop plant.

\section{Material and Methods}

The experiment was carried out near Pirassununga, state of São Paulo, Brazil (215' S, 4710' W, 650 m a.s.1.). The climate, according to the Köeppen classification, is of the Aw type: tropical of savanna. Based on 30 years of meteorological data from the location, the annual average temperature is $21.7^{\circ} \mathrm{C}$ and the annual average rainfall is $1,343 \mathrm{~mm}$, with higher frequency between December and March (840 mm) (Sentelhas et al., 2008). By using the climatological water balance method of Thornthwaite and Mather (1955), rainfall exceeds potential evapotranspiration between December and March, producing a water excess of $381 \mathrm{~mm}$. The soil is a Typic Eutrustox (Table 1 and 2) of sandy clay loam texture, with a water table over the depth of $10 \mathrm{~m}$. The methodology used in this study was similar to that presented by Ghiberto et al. (2009).

Before sugarcane planting, $2 \mathrm{t} \mathrm{ha}{ }^{-1}$ of dolomite limestone was applied over the entire experimental area. Then, the sugarcane (variety SP81-3250) was planted and fertilized with urea $\left(120 \mathrm{~kg} \mathrm{ha}^{-1}\right.$ of $\left.\mathrm{N}\right)$ in the planting furrow between February 21 and 24, 2005. In addition, 120

Table 1 - Chemical attributes of the soil.

\begin{tabular}{|c|c|c|c|c|c|c|c|c|c|c|c|}
\hline \multirow{2}{*}{$\begin{array}{l}\text { Soil } \\
\text { Horizon }\end{array}$} & \multirow{2}{*}{ Depth } & \multicolumn{3}{|c|}{$\mathrm{pH}$} & \multirow{2}{*}{$\mathrm{P}$} & \multirow{2}{*}{$\mathrm{K}$} & \multirow{2}{*}{$\mathrm{Ca}$} & \multirow{2}{*}{$\mathrm{Mg}$} & \multirow{2}{*}{$\mathrm{Al}$} & \multirow{2}{*}{$\mathrm{H}+\mathrm{Al}$} & \multirow{2}{*}{ CEC } \\
\hline & & $\mathrm{H}_{2} \mathrm{O}$ & $\mathrm{KCl}$ & $\Delta \mathrm{pH}$ & & & & & & & \\
\hline & $\mathrm{m}$ & & & & $\mathrm{mg} \mathrm{kg}^{-1}$ & $\ldots$ & $\ldots$ & $-\mathrm{mr}$ & $\mathrm{xg}^{-1}$ & $\ldots$ & 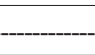 \\
\hline$A_{p}$ & 0.20 & 7.2 & 6.2 & -1 & 10 & 1.9 & 43 & 11 & 0 & 8 & 63.9 \\
\hline $\mathrm{BA}$ & 0.44 & 6.5 & 6.1 & -0.4 & 1 & 2.6 & 7 & 3 & 0 & 11 & 23.6 \\
\hline $\mathrm{B}_{\mathrm{w} 1}$ & 0.81 & 6.9 & 6.2 & -0.7 & 2 & 2.5 & 11 & 4 & 0 & 10 & 27.5 \\
\hline $\mathrm{B}_{\mathrm{w} 2}$ & $0.81^{+}$ & 6.4 & 6.1 & -0.3 & 1 & 1.8 & 18 & 7 & 0 & 11 & 37.8 \\
\hline
\end{tabular}

Table 2 - Particle size distribution, bulk density $\left(\rho_{\mathrm{b}}\right)$, particle density $\left(\rho_{\mathrm{p}}\right)$ and total porosity (TP) of the soil.

\begin{tabular}{|c|c|c|c|c|c|c|}
\hline \multirow{2}{*}{ Depth } & \multicolumn{3}{|c|}{ Particle size distribution } & \multirow[b]{2}{*}{$\rho_{\mathrm{b}}$} & \multirow[b]{2}{*}{$\rho_{\mathrm{p}}$} & \multirow{2}{*}{$\mathrm{TP}$} \\
\hline & Sand & Silt & Clay & & & \\
\hline $\mathrm{m}$ & \multicolumn{3}{|c|}{$\mathrm{g} \mathrm{kg}^{-1} \ldots$} & \multicolumn{2}{|c|}{$\mathrm{kg} \mathrm{m}^{-3}$} & $\%$ \\
\hline 0.1 & 733 & 52 & 215 & 1609 & 2681 & 40.0 \\
\hline 0.2 & 720 & 60 & 220 & 1688 & 2673 & 36.7 \\
\hline 0.3 & 705 & 55 & 240 & 1681 & 2682 & 37.3 \\
\hline 0.4 & 678 & 77 & 245 & 1532 & 2685 & 43.0 \\
\hline 0.5 & 695 & 50 & 255 & 1528 & 2693 & 43.3 \\
\hline 0.6 & 658 & 73 & 270 & 1451 & 2694 & 46.1 \\
\hline 0.7 & 673 & 48 & 280 & 1407 & 2692 & 55.6 \\
\hline 0.8 & 635 & 80 & 285 & 1392 & 2694 & 48.3 \\
\hline 0.9 & 675 & 40 & 285 & 1427 & 2695 & 47.1 \\
\hline 1.0 & 635 & 78 & 288 & 1298 & 2695 & 51.8 \\
\hline
\end{tabular}

Particle size distribution: pipette method; $\rho_{\mathrm{b}}$ : undisturbed soil samples in $0.05 \times 0.05 \mathrm{~m}$ cores; $\rho_{\mathrm{p}}$ : helium pycnometer; TP= $\left(1-\rho_{\mathrm{b}} / \rho_{\mathrm{p}}\right)$. 
$\mathrm{kg} \mathrm{ha}^{-1}$ of $\mathrm{K}_{2} \mathrm{O}$ and $\mathrm{P}_{2} \mathrm{O}_{5}$ with the sources potassium chloride $(\mathrm{KCl})$ and triple superphosphate, respectively, were also applied. To determine the fate of the $\mathrm{N}$-fertilizer, four microplots were installed. They consisted of $2.0 \mathrm{~m}$ of planting line, i.e., $2.0 \mathrm{~m} \times 1.5 \mathrm{~m}$ since the spacing between the rows is $1.5 \mathrm{~m}$ (Trivelin et al., 1994), in which nitrogen fertilizer enriched to $5.04{ }^{15} \mathrm{~N}$ At\% was applied.

Input and output of $\mathrm{N}$ ions, at the $0.9 \mathrm{~m}$ depth, were evaluated from the flux densities of water and the ion concentrations; tensiometers, the soil water retention curve and soil solution extractors with porous cups were used for this purpose. The equipment was installed in the field at the end of August 2005, just after leveling of the soil between plant rows. Because it was not possible to install the equipments before leveling the soil between plant rows, there was the delay between fertilization and beginning of the measurements. For this it was assumed that the release of $\mathrm{N}$ was low because of the high incorporation of crop residues with a $\mathrm{C} / \mathrm{N}$ of around 100, which facilitates the immobilization process (Oliveira et al., 1999). On other hand, near the town of Pirassununga, in the period without measurements, the climatological water balance is negative, which means that there is no surplus water to drain and transport solutes below the root-zone.

One tensiometer was installed at each of the depths of $0.8,0.9$ and $1.0 \mathrm{~m}$, and a solution extractor was installed at the depth of $0.9 \mathrm{~m}$ in each microplot. The 0.9 $\mathrm{m}$ depth was adopted because in this region, most sugarcane root biomass is found close to the soil surface; in fact, $80 \%$ occurs within the top $0.6 \mathrm{~m}$ (Ball-Coelho et al., 1992; Smith et al., 2005). Ion movement was measured by integrating the daily ion flux density over the time period, as indicated in equation (1) for $\mathrm{NO}_{3}^{-}$:

$\mathrm{q}_{\mathrm{NO}_{3}^{-}}=\int_{\mathrm{t}_{0}}^{\mathrm{t}_{\mathrm{t}}} \mathrm{q}_{\mathrm{w}} \mathrm{C}_{\mathrm{NO}_{3}^{-}} \mathrm{dt}$

where $\mathrm{q}_{\mathrm{NO}_{3}^{-}}\left(\mathrm{kg} \mathrm{ha}^{-1}\right)$ is the flow of nitrate in the soil, $\mathrm{q}_{\mathrm{w}}$ is the soil water flux density $\left(\mathrm{m} \mathrm{d}^{-1}\right)$, and $\mathrm{C}_{\mathrm{NO}_{3}^{-}}$is the concentration of nitrate in the soil solution $\left(\mathrm{kg} \mathrm{L}^{-1}\right)$ at the moment of measurement. $t_{0}$ and $t_{f}$ represent the initial time (equipment installation) and final time (harvest) of the experiment. The same procedure was carried out to estimate the flow of $\mathrm{NO}_{2}^{-}$and $\mathrm{NH}_{4}^{+}$.

The soil water flux density at the depth of $0.9 \mathrm{~m}$ was estimated from August/2005 (installation of equipment) until June/2006 (sugarcane harvest) using the DarcyBuckingham equation (equation 2):

$\theta_{\mathrm{w}}=-\mathrm{K}(\theta) \Delta\left(\psi_{\mathrm{t}}\right) / \mathrm{L}$

where $\mathrm{K}(\theta)$ is the soil hydraulic conductivity $\left(\mathrm{m} \mathrm{d}^{-1}\right)$ as a function of the volumetric water content $(\theta)$, or $\mathrm{K}(\theta)$ function, and $\Delta \psi_{\mathrm{t}} / \mathrm{L}$ is the soil water total potential gradient, both at the depth of $0.9 \mathrm{~m}$.

The volumetric soil water content, used to estimate $\mathrm{K}$ during the experiment, was obtained from daily readings of the tensiometers and the soil water retention curve at the depth of $0.9 \mathrm{~m}$. The gradient $\left(\mathrm{Dy}_{\mathrm{t}} / \mathrm{L}\right)$ at the depth of
$0.9 \mathrm{~m}$ was calculated by finite difference from daily readings of tensiometers at the depths of $0.8 \mathrm{~m}$ and $1.0 \mathrm{~m}$. The $\mathrm{K}(\theta)$ function was determined by the instantaneous profile method (Hillel et al., 1972) by means of equation (3):

$\mathrm{K}(\theta)=\mathrm{K}_{0} \operatorname{exp\gamma }\left(\theta-\theta_{0}\right)$

in which $\mathrm{K}_{\mathrm{o}}=443.3 \mathrm{~mm} \mathrm{~d}^{-1}$ (at time zero of soil water redistribution); $\gamma=52.232$ and $\theta_{o}=0.366 \mathrm{~m}^{3} \mathrm{~m}^{-3}$ (at time zero of soil water redistribution).

Soil bulk density $\left(\mathrm{r}_{\mathrm{b}}\right)$ was determined at depths of 0.1 , $0.2,0.3,0.4,0.5,0.6,0.7,0.8,0.9$ and $1.0 \mathrm{~m}$ using an Uhland sampler. Three soil cores (diameter of $0.05 \mathrm{~m}$ and height of $0.05 \mathrm{~m}$ ) were taken per depth. The soil water retention curve at the $0.9 \mathrm{~m}$ depth was determined for the matric potentials $-0.5,-1,-3,-5,-7$ and $-10 \mathrm{kPa}$ by using porous plate funnels and, for $-30,-50,70$ and $-100 \mathrm{kPa}$, in Richard's pressure cells. Three soil cores were saturated and equilibrated at each potential, and then the gravimetric and volumetric soil water content was calculated using the soil bulk density. Finally, the data were adjusted to equation (4) (van Genuchten, 1980):

$\theta=\theta_{\mathrm{r}}+\left(\theta_{\mathrm{s}}-\theta_{\mathrm{r}}\right)\left[1+\left(\mathrm{a}\left|\psi_{\mathrm{m}}\right|\right)^{\mathrm{n}}\right]^{-\mathrm{m}}$

where $\theta_{\mathrm{s}}=0.455 \mathrm{~m}^{3} \mathrm{~m}^{-3}$ is the saturated soil water content; $\theta_{\mathrm{r}}=0.126 \mathrm{~m}^{3} \mathrm{~m}^{-3}$ is the soil residual water content; $\alpha=0.542 \mathrm{kPa}, \mathrm{n}=5.0463$ and $\mathrm{m}=0.1668$ are adjustment parameters; and $\mathrm{y}_{\mathrm{m}}$ is the matric potential.

The solution taken from the soil was filtered (millipore cellulose filter paper $0.45 \mu \mathrm{m}$ ) and the concentration of the ions $\mathrm{NH}_{4}^{+}, \mathrm{NO}_{3}^{-}$and $\mathrm{NO}_{2}^{-}$determined by ion chromatography (DIONEX ICS-90). The ${ }^{15} \mathrm{~N}$ analyses to quantify the $\mathrm{N}$ in the soil solution derived from fertilizer were made by means of a mass spectrometer (ANCA-GSL by Secon). However, composite samples from each extractor were used in sequence to obtain reliable measurements on the mass spectrometer when the total mineral $\mathrm{N}$ content in the sample was less than 150 to $250 \mathrm{mg} \mathrm{N}$. Thereafter, each sample was concentrated by distillation in alkaline medium with Devarda alloy (Cantarella and Trivelin, 2001). The percentage of nitrogen in the soil solution derived from the fertilizer (\%NSSDF) was calculated by equation (5), adapted from Hauck et al. (1994):

$\% \mathrm{NSSDF}=\left[\left(\right.\right.$ Atom $_{\text {solution }_{\text {in }}}-$ Atom $\left.\%_{\text {soi }}\right) /\left(\right.$ Atom $\%_{\text {fertilizer }}-$ Atom $\left.\left.\%_{\text {soil }}\right)\right] \times 100$

where Atom $\%$ is the ${ }^{15} \mathrm{~N}$ abundance of the fertilizer $(5.04 \%)$ and of the soil $(0.367 \%)$.

The soil water storage $(\mathrm{H})$ was determined by the gravimetric method in each replicate by sampling of the following soil layers: $0-0.15,0.15-0.25,0.25-0.35,0.35$ $0.45,0.45-0.55,0.55-0.65,0.65-0.75,0.75-0.85,0.85$ 0.95 and $0.95-1.05 \mathrm{~m}$, approximately every $20 \mathrm{~d}$. Each sample was placed in an aluminum can, hermetically sealed, and transported to the laboratory, where the gravimetric and volumetric soil water contents were determined using the soil bulk density of each depth and then calculating the soil water storage (Gardner, 1986). 
Daily rainfalls were measured by means of a pluviometer installed at the experiment site and compared to the historical series of Pirassununga between 1939 and 2004, obtained from the pluviometric database of the State of São Paulo.

\section{Results and Discussion}

Rainfall between September 1, 2005 and May 31, 2006 amounted to $1,174 \mathrm{~mm}$, which is $141 \mathrm{~mm}$ less than the historical average over the same period $(1,315 \mathrm{~mm})$ (Table 3). Even though January is the rainiest month of the year, rainfall was recorded to be $71 \mathrm{~mm}$ less than normal. On the other hand, February exceeded the average by $103 \mathrm{~mm}$. According to Tollner (2002), the return period of an equal or greater event for February is seven years. The rainfall distribution was similar to the historical average in the remaining months of monitoring.

From December 5, 2005 to December 22, 2005, the soil water storage down to a depth of $0.9 \mathrm{~m}$ increased by $48 \mathrm{~mm}$ following an increase in the rainfall of 116 $\mathrm{mm}$ (Figure 1). After this period, the soil profile had a volumetric soil water content around the field capacity (FC) until January 10, $2006\left(\mathrm{FC}=0.237 \mathrm{~m}^{3} \mathrm{~m}^{-3}\right.$ for $\psi_{\mathrm{m}}=$ $-10 \mathrm{kPa}$ ). Next, during the phenological phase of maximum growth of sugarcane (Franco 2008), with high water demand by the crop and coinciding with a period of low precipitation, the soil water storage decreased (Janu- ary, Table 3 and Figure 1). Then, with atypical rainfalls in late February, the storage of water was elevated in the period of February 21, 2006 to April 12, 2006.

The evolution of the volumetric soil water content at $0.9 \mathrm{~m}$ depth was similar to the storage of water in the soil profile during the monitoring period (Figure 1). The volumetric water content $(\theta)$, inferred from the tensiometer readings, was less than $0.15 \mathrm{~m}^{3} \mathrm{~m}^{-3}$ from the beginning of the experiment to December 24, 2005. After that, there was an increase in $\theta$, with the maximum value of $0.278 \mathrm{~m}^{3} \mathrm{~m}^{-3}$ at January 5,2006 . According to the results, $\theta$ never reached saturation $\left(\theta_{\mathrm{s}}=0.455 \mathrm{~m}^{3} \mathrm{~m}^{-3}\right.$, adjustment parameter of equation 4) or $\theta_{\text {o }}$ (parameter of the $\mathrm{K}(\theta)$ function of equation 3 ), but exceeded in three circumstances the field capacity at the depth of $0.9 \mathrm{~m}$.

It was possible to extract the soil solution only in the period between December 26, 2005 and April 28, 2006, when the soil water matric potential was higher than $-40 \mathrm{kPa}$. The mean mineral $\mathrm{N}$ concentration during the experiment was $1.8 \mathrm{mg} \mathrm{L}^{-1}$ with a standard deviation of 2.2. At the beginning of the extraction period, the $\mathrm{N}$ concentration was higher than in the later period (Figure 2). The At\% of ${ }^{15} \mathrm{~N}$ was higher than the natural abundance of the isotope $\left(0.367 \mathrm{At} \%\right.$ of $\left.{ }^{15} \mathrm{~N}\right)$ from the beginning of the evaluation period, decreasing subsequently and remaining almost constant $\left(0.453 \mathrm{At} \%\right.$ of $\left.{ }^{15} \mathrm{~N}\right)$ from December 28, 2005 to February 15, 2006 (Figure 2).

Coinciding with the rain periods 3,5 and 7 , the volumetric soil water content exceeded field capacity and

Table 3 - Monthly average rainfall in Pirassununga in the period 1939-2004 and during the months of the experiment.

\begin{tabular}{lccccccccc}
\hline \multirow{2}{*}{ Year } & \multicolumn{8}{c}{ Monthly rainfall distribution (mm) } \\
\cline { 2 - 11 } & Sep. & Oct. & Nov. & Dec. & Jan. & Feb. & Mar. & Apr. & May \\
\hline $2005 / 2006$ & 61 & 121 & 153 & 230 & 244 & 217 & 166 & 69 & 54 \\
$65 \mathrm{yr}$ average & 56 & 79 & 56 & 233 & 173 & 320 & 202 & 53 & 3 \\
\hline
\end{tabular}

Table 4 - Rainfall, drained water and nitrogen flow in the soil at various periods; positive numbers indicate gains and negative numbers indicate losses of water and nitrogen at the depth of $0.9 \mathrm{~m}$.

\begin{tabular}{|c|c|c|c|c|c|c|c|c|}
\hline \multicolumn{2}{|c|}{ Period } & \multirow{2}{*}{ Rainfall } & \multirow{2}{*}{ Drainage } & \multicolumn{5}{|c|}{$\mathrm{N}$ leaching ${ }^{\dagger}$} \\
\hline $\mathrm{N}^{\circ}$ & Date & & & N-TOTAL & $\mathrm{N}^{-\mathrm{NO}_{2}-}$ & $\mathrm{N}^{-\mathrm{NO}_{3}-}$ & $\mathrm{N}_{-\mathrm{NH}_{4}+}$ & ${ }^{15} \mathrm{~N}-F e r t$. \\
\hline & & $\mathrm{mm}$ & & - & 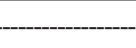 & $-\mathrm{kg} \mathrm{ha}^{-1}$ & & 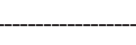 \\
\hline 1 & $08 / 24-11 / 30$ & 191 & $0.1(0.7)$ & $0.0(0.0)$ & 0.000 & 0.014 & 0.001 & 0.004 \\
\hline 2 & $12 / 01-12 / 14$ & 61 & $-0.1(0.0)$ & $0.0(0.0)$ & 0.000 & -0.006 & -0.001 & -0.002 \\
\hline 3 & $12 / 15-01 / 08$ & 326 & $-22.3(11.4)$ & $-0.4(0.4)$ & -0.010 & -0.226 & -0.155 & -0.043 \\
\hline 4 & $01 / 09-01 / 31$ & 19 & $-0.9(1.1)$ & $0.0(0.0)$ & 0.000 & -0.001 & -0.006 & 0.000 \\
\hline 5 & $02 / 01-02 / 20$ & 297 & $-49.4(32.4)$ & $-0.6(0.3)$ & -0.087 & -0.162 & -0.354 & -0.010 \\
\hline 6 & $02 / 21-03 / 18$ & 92 & $-4.1(1.1)$ & $0.0(0.0)$ & -0.005 & -0.007 & -0.035 & -0.001 \\
\hline 7 & $03 / 19-03 / 29$ & 131 & $-9.6(12.2)$ & $-0.1(0.0)$ & -0.011 & -0.023 & -0.028 & -0.001 \\
\hline 8 & $03 / 30-05 / 31$ & 58 & $-4.7(2.0)$ & $0.0(0.0)$ & -0.010 & -0.011 & -0.027 & -0.001 \\
\hline Total & & 1175 & $-91.0(60.9)$ & $-1.1(0.7)$ & -0.123 & -0.422 & -0.605 & -0.054 \\
\hline
\end{tabular}

The numbers shown for each period represent the average of four repetitions, and the respective standard deviations. The number shown as the total of the cycle is the sum of each period and the respective standard deviation propagated. ( $\dagger$ ) In the experiment: 120 $\mathrm{kg} \mathrm{ha}^{-1}$ of $\mathrm{N} ; 120 \mathrm{~kg} \mathrm{ha}^{-1}$ of $\mathrm{K}_{2} \mathrm{O}$ and $\mathrm{P}_{2} \mathrm{O}_{5}$; and $2 \mathrm{tha}^{-1}$ of dolomite limestone were applied. 


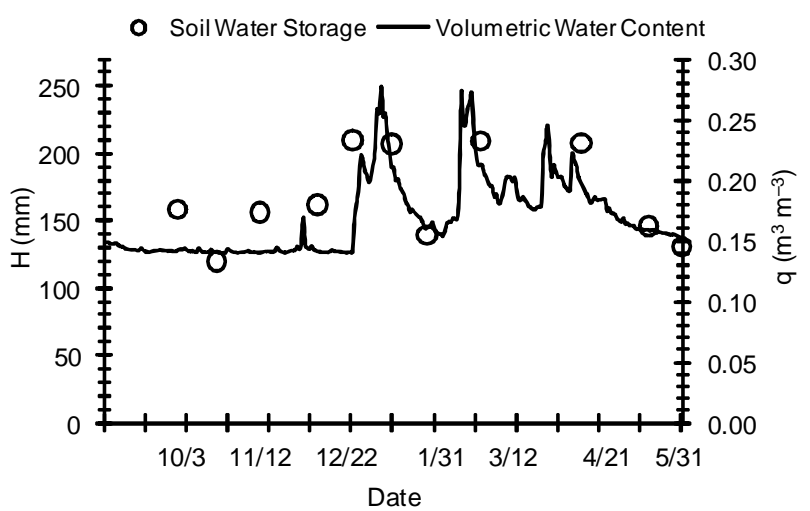

Figure 1 - Evolution of the volumetric water content $(\theta)$, average of four repetitions (full line) at $0.9 \mathrm{~m}$ of depth, and soil water storage $(\mathrm{H})$ until $0.9 \mathrm{~m}$ depth during the months of monitoring.

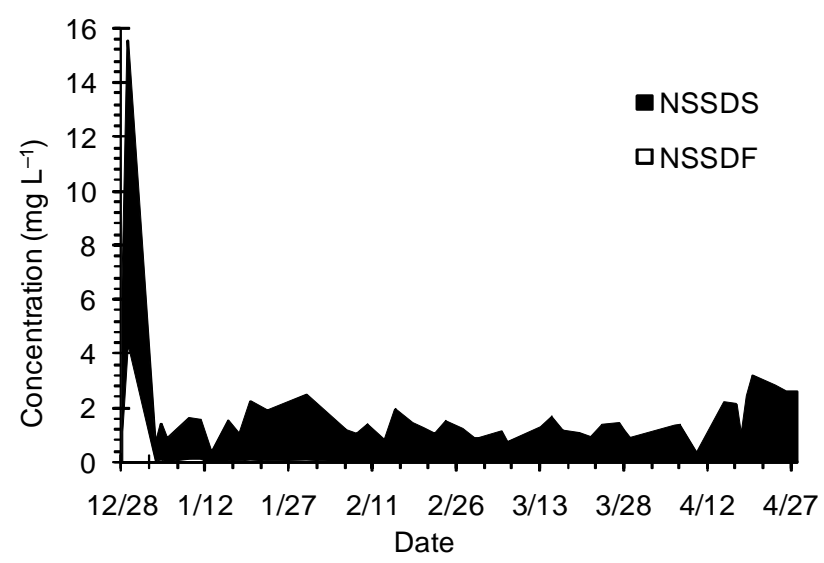

Figure 2 - Concentration of nitrogen in the soil solution derived from soil (NSSDS) and N derived from fertilizer (NSSDF) during the months of monitoring.

there was an increase of the water flux at the $0.9 \mathrm{~m}$ depth (Table 4). In the other periods, internal drainage was lower because $\theta$ was smaller than $0.236 \mathrm{~m}^{3} \mathrm{~m}^{-3}$ (Figure 1), which corresponded to a $\mathrm{K}$ of $0.5 \mathrm{~mm} \mathrm{~d}^{-1}$ (equation 3). On average, $91 \mathrm{~mm}$ were drained during all cycles, which was $290 \mathrm{~mm}$ less than the surplus of $381 \mathrm{~mm}$ calculated by the climatological water balance method of Thornthwaite and Mather (1955), as described by Sentelhas et al. (2008). The capillary rise throughout the cycle was very low, about $1 \mathrm{~mm}$ (Brito et al., 2009).

Leaching $\mathrm{N}$ losses occurred mainly during periods 3 and 5 (Table 4), when the drainage was higher (Figure 3). The total amount of $\mathrm{N}$ loss was $1.1 \mathrm{~kg} \mathrm{ha}^{-1}$, of which $37 \%$ was as $\mathrm{N}^{-\mathrm{NO}_{3}}{ }_{3}^{-}, 11 \%$ as $\mathrm{N}-\mathrm{NO}_{2}{ }^{-}$and $52 \%$ as $\mathrm{N}^{-} \mathrm{NH}_{4}^{+}$. From the analysis of the ${ }^{15} \mathrm{~N}$ isotope in the soil solution, only $54 \mathrm{~g} \mathrm{ha}^{-1}$ of nitrogen from the applied fertilizer $(120$ $\mathrm{kg} \mathrm{ha}^{-1}$ ) was leached during the crop plant cycle.

The amount of leached $\mathrm{N}$, both native and derived from fertilizer, was low, as observed in other studies with sugarcane ( $\mathrm{Ng}$ Kee Kwong and Deville, 1984; Southwick et al., 1995). In field studies, Oliveira et al. (2000) did not find substantial amounts of $\mathrm{N}$ leached at $1.0 \mathrm{~m}$ depth in a Rodic Kandiudalf. In this case, a smaller

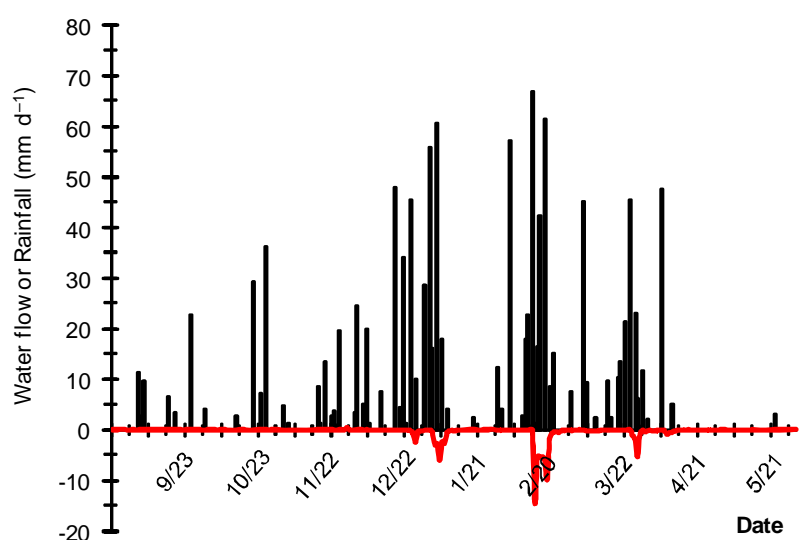

Figure 3 - Daily rainfall (bars) and water flow during the studied period (full line). Positive numbers indicate gain and negative numbers indicate loss of water in the system.

dose of fertilizer $\mathrm{N}$ was used $\left(63 \mathrm{~kg} \mathrm{ha}^{-1}\right.$ de $\mathrm{N}-$ $\left.\left(\mathrm{NH}_{4}\right)_{2} \mathrm{SO}_{4}\right)$ and crop $\mathrm{N}$ use efficiency $(60 \%)$ was higher than the 10 to $40 \%$ recovery usually registered in other experiments (Chapman et al., 1994; Trivelin et al., 1995; Vallis et al., 1996). Using containers of $220 \mathrm{~L}$, with the root system confined to an unrepresentative volume, Trivelin et al. (2002) and Oliveira et al. (2002) showed that the total amount of leached $\mathrm{N}$ was $4.5 \mathrm{~kg} \mathrm{ha}^{-1}$ (none of which was from the urea fertilizer), $53 \%$ of which occurred in the first three weeks due to poor development of the sugarcane root system and higher rainfall in that period.

Although the observed leaching losses were low, other studies using tensiometers and soil solution extractors with porous cups between 0.8 and $1.20 \mathrm{~m}$ soil depths, with doses higher than $100 \mathrm{~kg} \mathrm{ha}^{-1}$ of $\mathrm{N}$, have registered leaching losses between 15 and $21 \mathrm{~kg} \mathrm{ha}^{-1}$ in a Typic Hapludox cultivated with corn (Fernandes et al., 2006), $15 \mathrm{~kg} \mathrm{ha}^{-1}$ in an Oxic Paleudalf cultivated with bean (Meirelles et al., 1980) and a maximum of $76 \mathrm{~kg}$ $\mathrm{ha}^{-1}$ of $\mathrm{N}$ in a Typic Hapludox in the second ratoon of sugarcane (Oliveira et al., 2001). In all cases mentioned the water drained was greater than $200 \mathrm{~mm}$, in contrast with this work $(91 \mathrm{~mm})$. All these studies were performed in the State of São Paulo (Brazil) with similar climatological water balances to that of the Pirassununga, showing that leaching losses could be higher if the conditions are favorable.

The $\mathrm{N}$ concentration at $0.9 \mathrm{~m}$ depth was lower than $10 \mathrm{mg} \mathrm{L}^{-1}$, the maximum limit for human consumption, in contrast to the findings of Oliveira et al. (2001), who detected water quality alteration with an increase of the mean soil solution concentration at $0.9 \mathrm{~m}$ depth from 0.74 to $14.58 \mathrm{mg} \mathrm{L}^{-1}$ when 0 and $120 \mathrm{~kg} \mathrm{ha}^{-1}$ of fertilizer $\mathrm{N}$ was applied to sugarcane. The concentration of $\mathrm{N}$ in the soil solution at $0.9 \mathrm{~m}$ depth was one of the causes of low loss by leaching.

Individual events of high precipitation (Figure 3), when the soil profile was close to field capacity (Figure 1), caused the higher values of drainage in the cycle (around $19 \mathrm{~mm} \mathrm{~d}^{-1}$ ). In consequence, $\mathrm{N}$ could easily be 
lost since $\mathrm{N}$ was available in the soil, especially considering the predominance of negative charges in the soil with low capacity of nitrate adsorption (see $\Delta \mathrm{pH}$ in Table 1). Ghiberto et al. (2009) applied $120 \mathrm{~kg} \mathrm{ha}^{-1}$ as labeled ${ }^{15} \mathrm{~N}$ urea to a sandy-clay-loam Arenic Kandiustults cultivated with sugarcane in a crop plant cycle, and measured leaching losses at $0.9 \mathrm{~m}$ using tensiometers and soil solution extractors with porous cups. Ghiberto et al. (2009) found that $18 \mathrm{~kg} \mathrm{ha}^{-1}$ of $\mathrm{N}$ were leached, mainly as nitrate, and that only $25 \mathrm{~g} \mathrm{ha}^{-1}$ was derived from the fertilizer. The soils of both experiments have similar textural class, hydraulic properties and millable stalk production; the main difference was the amount and distribution of rainfall during the period in which the surplus, calculated by the climatological water balance, normally takes place (December-March). In this study, compared to the experiment of Ghiberto et al. (2009), $115 \mathrm{~mm}$ less was drained and the month of January was drier than normal, as mentioned in the results.

The production of millable stalks was $141 \mathrm{t} \mathrm{ha}^{-1}(26 \%$ of dry matter). The amount of $\mathrm{N}$ uptake by the crop (167 $\mathrm{kg} \mathrm{ha}{ }^{-1}$ ) was greater than the amount applied by fertilization $\left(120 \mathrm{~kg} \mathrm{ha}^{-1}\right)$. So, the high demand of $\mathrm{N}$ may restrict the leaching of $\mathrm{N}$. The crop $\mathrm{N}$ uptake was distributed as follows: $46 \%$ in stalks, $15 \%$ in dry leaves, $22 \%$ in shoots, $7 \%$ in roots and $10 \%$ in rhizomes. The $\mathrm{N}$ recovered from the fertilizer by the crop was $25.4 \mathrm{~kg} \mathrm{ha}^{-1}$ in the whole plant, representing $21 \%$ of the applied fertilizer (Franco et al., 2008). In this experiment, at the end of the crop cycle, sugarcane residue was not burnt before harvest and it is estimated that $90 \mathrm{~kg} \mathrm{ha}^{-1}$ of $\mathrm{N}$ remained in the field; this could be used in the subsequent first ratoon.

Leaching increases markedly when the nitrogen application rate is higher than that recommended for the crop (Thorburn et al., 2003). However, the soil $\mathrm{N}$ balance was negative when ignoring $\mathrm{N}$ input to the system arising from rainfall and biological fixation. In Brazil, the recommended $\mathrm{N}$ doses in sugarcane crops are not as high as those used in other countries such as Australia (150-250 kg ha ${ }^{-1}$ ) (Gourley and Ridley, 2005; Stewart et al., 2006). Thus, it appears that an increase in crop $\mathrm{N}$ use efficiency is beneficial, not only from the environmental point of view, but also due to the reduction of costs by reduced use of nitrogen fertilizer (Chapman et al., 1994).

In periods in which the water flow and leaching were greater, sugarcane was at the phenological stage of maximum growth with high demand for water and nutrients, thus contributing to avoid excessive loss of N. Based on data of Franco et al. (2008) estimated that for periods 3 and 5 (Table 4), the sugarcane accumulated 5,047 and $4,461 \mathrm{~kg} \mathrm{ha}^{-1}$ of dry matter, respectively. According to Brito et al. (2009), the average actual evapotranspiration was 11 and $8 \mathrm{~mm} \mathrm{~d}^{-1}$, respectively, showing that the demand for $\mathrm{N}$ and water was high. Similarly, Stewart et al. (2006) used the simulation model APSIM-SWIM to show that of the $29.5 \mathrm{~kg} \mathrm{ha}^{-1}$ of $\mathrm{N}-\mathrm{NO}_{3}$ transported by drainage, the plants absorbed $26.6 \mathrm{~kg} \mathrm{ha}^{-1}$ of $\mathrm{N}$ from the soil below the depth of 1.5 $\mathrm{m}$ at the end of the cycle. It was concluded that the net amount of $\mathrm{N}$ lost by leaching into the water table was $2.9 \mathrm{~kg} \mathrm{ha}^{-1} \mathrm{~N}-\mathrm{NO}_{3}$.

The $\mathrm{N}$ uptake by the crop was mainly native; however, the low fertilizer-N recovery $(21 \%)$ by the whole plant (Franco et al., 2008) was not caused by higher $\mathrm{N}$ leaching losses. Since volatilization was prevented at planting by incorporation of urea (Chapman et al., 1994; Franco et al., 2008; Trivelin et al., 2002), we hypothesize that the fertilizer $\mathrm{N}$ was immobilized in the soil organic pool at the same time that soil organic $\mathrm{N}$ was mineralized (Jansson and Persson, 1982). Furthermore, the high $\mathrm{C} / \mathrm{N}$ ratio $(80-120)$ of the residue results in an initial immobilization of soil mineral $\mathrm{N}$ and provision of little $\mathrm{N}$ available for crop uptake in the year after deposition (Thorburn et al., 2005), reinforcing the idea. This is especially important in sugarcane systems without straw burning where immobilization takes place (Basanta et al., 2003; Meier et al., 2006; Wood, 1991), and supports the conclusion of interference in biological $\mathrm{N}$ immobilization having an effect on the downward movement of fertilizer N (Ng Kee Kwong and Deville, 1987). There are few studies about leaching in this condition and in 2007 in the State of São Paulo, 40\% of the harvest took place without burning (Goldemberg et al., 2008). In other studies, despite the low $\mathrm{N}$ leaching losses, significant amounts of $\mathrm{K}, \mathrm{Ca}$ and $\mathrm{Mg}$ should have leached, which may result in soil acidification (Cahn et al., 1993; Ghiberto et al., 2009; Ng Kee Kwong and Deville, 1984; Oliveira et al., 2002). This is important if we consider that acidification is reversible by liming, but when it takes place in the subsoil, amelioration is much more difficult and expensive (Hartemink, 2008).

\section{Conclusion}

During the agricultural cycle of the crop plant, the leaching of $\mathrm{N}$ was not considerable, mainly because the surplus of water between the months of December and March was lower than expected; the high demand of $\mathrm{N}$ by the crop; and the analyzed cropping system did not include straw burning before planting.

\section{Acknowledgements}

To the financial support by FAPESP and CAPES, to the logistical support of the São Luiz Mill, and to the support of the laboratory analyses by the technicians at the Laboratory of Stable Isotopes at CENA.

\section{References}

Ball-Coelho, B.; Sampaio, E.V.S.B.; Tiessen, H.; Stewart, J.W.B. 1992. Root dynamics in plant and ratoon crops of sugar cane. Plant and Soil 142: 297-305. 
Basanta, M.V.; Dourado-Neto, D.; Reichardt, K.; Bacchi, O.O.S.; Oliveira, J.C.M.; Trivelin, P.C.O.; Timm, L.C.; Tominaga, T.T.; Corrochel, V.; Cássaro, F.A.M.; Pires, L.F.; De Macedo, V. 2003. Management effects on nitrogen recovery in a sugarcane crop grown in Brazil. Geoderma 116: 235-248.

Brito, A.S.; Libardi, P.L.; Ghiberto, P.J. 2009. Water flux density, actual evapotranspiration and water storage in two sugar-cane cropped soils. Revista Brasileira de Ciência do Solo 30: 295-303. (in Portuguese, with abstract in English).

Cahn, M.D.; Bouldin, D.R., Cravo; M.S., Bowen, W.T. 1993. Cation and nitrate leaching in an Oxisol of the Brazilian Amazon. Agronomy Journal 85: 334-340.

Cantarella, H.; Trivelin, P.C.O.; Vitti, A.C. 2007. Nitrogen and sulphur in sugarcane. p. 355-412. In: Yamada, T.; Abdalla, S.R.S.; Vitti, G.C., eds. Nitrogen and sulphur in Brazilian agriculture. International Plant Nutrition Institute, Piracicaba, SP, Brazil. (in Portuguese).

Cantarella, H.; Trivelin, P.C.O. 2001. Inorganic nitrogen determination by the vapour distillation method. p. 270276. In: Raij, B.van; Andrade, J.C.; Cantarella, H.; Quaggio, J.A., eds. Chemical analysis to evaluate the fertility tropical soils. Instituto Agronômico, Campinas, SP, Brazil. (in Portuguese).

Chapman, L.S.; Haysom, M.B.C.; Saffigna, P.G. 1994. The recovery of ${ }^{15} \mathrm{~N}$ from labelled urea fertilizer in crop components of sugarcane and in soil profiles. Australian Journal of Agricultural Research 45: 1577-1585.

Fernandes, F.C.S.; Libardi, P.L.; Carvalho, L.A. 2006. Internal drainage and nitrate leaching in a corn-black oat-corn succession with two split nitrogen applications. Scientia Agricola 63: 483492.

Franco, H.C.J.; Trivelin, P.C.O.; Faroni, C.E.; Vitti, A.C.; Otto, R. 2008. Utilization of sugar cane of nitrogen applied at planting. Revista Brasileira de Ciência do Solo 32: 2763-2770. (in Portuguese, with abstract in English).

Gardner, W.T. 1986. Water content. p. 493-541. In: Black, C.A., ed. Methods of soil analysis. Part I. Physical and mineralogical methods. American Society of Agronomy, Madison, WI, USA.

van Genuchten, M.T. 1980. A closed-form equation for predicting the hydraulic conductivity of unsaturated soils. Soil Science Society of America Journal 44: 892-898.

Ghiberto, P.J.; Libardi, P.L.; Brito, A.S.; Trivelin, P.C.O. 2009. Leaching of nutrients from a sugarcane crop growing on an Ultisol in Brazil. Agricultural Water Management 96: 14431448.

Goldemberg, J.; Coelho, S.T.; Guardabassi, P. 2008. The sustainability of ethanol production from sugarcane. Energy Policy 36: 2086-2097.

Gourley, C.; Ridley, A. 2005. Controling non-point source pollution in Australian agricultural systems. Pedosphere 15: 768-777.

Hartemink, A.E. 2008. Sugarcane for bioethanol: soil and environmental issues. Advances in Agronomy 99: 125-182.

Hauck, R.D.; Meisinger, J.J.; Mulvaney, R.L. 1994. Practical considerations in the use of nitrogen tracers in agricultural and environmental research. p. 907-943. In: Mickelson, S.H.; Bigham, J.M., eds. Methods of soil analysis. Part II. Microbiological and biochemical properties. Soil Science Society of America, Madison, WI, USA.

Hillel, D.; Krentos, V.D.; Stylianou, Y. 1972. Procedure and test of an internal drainage method for measuring soil hydraulic characteristic in situ. Soil Science Society of America Journal 114: 395-400.

Jansson, S.L.; Persson, J. 1982. Mineralization and immobilization of soil nitrogen. p. 467-502. In: Stevenson, F.J.; Bremmer, J.M.; Hauck, R.D.; Keeney, D.R., eds. Nitrogen in agricultural soils. American Society of Agronomy, Madison, WI, USA.

Martinelli, L.A.; Filoso, S. 2008. Expansion of sugarcane ethanol production in Brazil: environmental and social challenges. Ecological Applications 18: 885-898.
Meier, E.A.; Thorburn, P.J.; Wegener, M.K.; Basford K.E. 2006. The availability of nitrogen from sugarcane trash on contrasting soils in the wet tropics of North Queensland. Nutrient Cycling in Agroecosystems 75: 101-114.

Meirelles, N.M.F.; Libardi, P.L.; Reichardt, K. 1980. Absorption and leaching of nitrogen in bean crop (Phaseolus vulgaris L.) Revista Brasileira de Ciência do Solo 4: 83-88. (in Portuguese, with abstract in English).

Ng Kee Kwong, K.F.; Deville, J. 1987. Residual fertilizer nitrogen as influenced by timing and nitrogen forms in a silty clay soil under sugarcane in Mauritius. Nutrient Cycling in Agroecosystems 14: 219-226.

Ng Kee Kwong, K.F.; Deville, J. 1984. Nitrogen leaching from soils cropped with sugarcane under the humid tropical climate of Mauritius Indian Ocean. Journal of Environmental Quality 13: 471-474.

Oliveira, M.W.; Trivelin, P.C.O.; Boaretto, A.E.; Muraoka, T.; Moratti, J. 2002. Leaching of nitrogen, potassium, calcium and magnesium in a sandy soil cultivated with sugarcane. Pesquisa Agropecuária Brasileira 37: 861-868. (in Portuguese, with abstract in English).

Oliveira, F.C.; Mattiazzo, M.E.; Marciano, C.R.; Moraes, S.O. 2001. Nitrate leaching in a sewage sludge-amended Typic Hapludox cultivated with sugarcane. Scientia Agricola 58: 171-180. (in Portuguese, with abstract in English)

Oliveira, J.C.M.; Reichardt, K.; Bacchi, O.; Timm, L.C.; DouradoNeto, D.; Trivelin, P.C.O.; Tominaga, T.; Navarro, R.; Píccolo, M.; Cássaro, F. 2000. Nitrogen dynamics in a soil-sugar cane system. Scientia Agricola 57: 467-472. (in Portuguese, with abstract in English).

Oliveira, M.W.; Trivelin, P.C.O.; Penatti, C.P.; Piccolo, M. 1999. Field decomposition and release of sugar cane trash nutrients. Pesquisa Agropecuária Brasileira 34: 2359-2362. (in Portuguese, with abstract in English).

Sentelhas, P.C.; Pereira, A.R.; Marin, F.R.; Angelocci, L.R.; Alfonsi, R.R.; Caramori, P.H.; Swart, S. 2008. Climatological water balances in 500 Brazilian locations. Available in: http:// www.lce.esalq.usp.br/bhbrasil/Saopaulo. [Accessed Nov. 15, 2008].

Smith, D.M.; Inman-Bamber, N.G.; Thorburn, P.J. 2005. Growth and function of the sugarcane root system. Field Crops Research 92: 169-183.

Southwick, L.M.; Willis, G.H.; Johnson, D.C.; Selim, H.M. 1995. Leaching of nitrate, atrazine, and metribuzin from sugarcane in Southern Louisiana. Journal of Environmental Quality 24: 684690.

Stewart, L.K.; Charlesworth, P.B.; Bristow, K.L.; Thorburn, P.J. 2006. Estimating deep drainage and nitrate leaching from the root zone under sugarcane using APSIM-SWIM. Agricultural Water Management 81: 315-334.

Thorburn, P.J.; Meier, E.A.; Probert, M.E. 2005. Modelling nitrogen dynamics in sugarcane systems: recent advances and applications. Field Crops Research 92: 337-351.

Thorburn, P.J.; Biggs, J.S.; Weier, K.L.; Keating, B.A. 2003. Nitrate in groundwaters of intensive agricultural areas in coastal Northeastern Australia. Agriculture, Ecosystems and Environment 94: 49-48.

Thornthwaite, C.W.; Mather, J.R. 1955. The Water Balance. Drexel Institute of Technology, Philadelphia, PA, USA. (Publications in Climatology).

Tollner, E.W. 2002. Precipitation. p. 20-50. In: Tollner, E.W., ed. Natural resources engineering. Iowa State Press, Ames, IA, USA.

Trivelin, P.C.O.; Oliveira, M.W.; Vitti, A.C.; Gava, G.J.; Bendassolli, J.A. 2002. Nitrogen losses of applied urea in the soil-plant system during two sugar cane cycles. Pesquisa Agropecuária Brasileira 37: 193-201. (in Portuguese, with abstract in English). 
Trivelin, P.C.O.; Victoria, R.L.; Rodrigues, J.C.S. 1995. Utilization by late harvest sugar cane ratoon of nitrogen from ${ }^{15} \mathrm{~N}$-aqua ammonia and ${ }^{15} \mathrm{~N}$-urea applied to the soil as vinasse $\mathrm{N}$ complement. Pesquisa Agropecuária Brasileira 30: 1375-1385. (in Portuguese, with abstract in English).

Trivelin, P.C.O.; Lara Cabezas, W.A.R.; Victoria, R.L.; Reichardt, K. 1994. Evaluation of a ${ }^{15} \mathrm{~N}$ plot design for estimating plant recovery of fertilizer nitrogen applied to sugar cane. Scientia Agricola 51: 226-234. (in Portuguese, with abstract in English).

Uriarte, M.; Yackulic, C.B.; Cooper, T.; Flynn, D.; Cortes, M.; Crk, T.; Cullman, G.; McGinty, M.; Sircely, J. 2009. Expansion of sugarcane production in São Paulo, Brazil: implications for fire occurrence and respiratory health. Agriculture, Ecosystems \& Environment 132: 48-56.
Vallis, I.; Catchpoole, V.R.; Hughes, R.M.; Myers, J.K.; Ridge, D.R.; Weier, K.L. 1996. Recovery in plants and soils of ${ }^{15} \mathrm{~N}$ applied as subsurface bands of urea to sugarcane. Australian Journal of Agricultural Research 47: 355-370.

Wood, A.W. 1991. Management of crop residues following green harvesting of sugarcane in North Queensland. Soil and Tillage Research 20: 69-85.

Received October 29, 2009

Accepted July 16, 2010 